\title{
CRITICAL PEDAGOGY(IES) FOR ELT IN INDONESIA
}

\author{
Kasey R. Larson \\ (klarson@hawaii.edu) \\ University of Hawai $i$ at Mānoa \\ Department of Second Language Studies \\ Moore Hall 570, 1890 East-West Road, Honolulu, Hawai ‘i 96822
}

\begin{abstract}
This paper will explore the theoretical underpinnings that present a rationale for the use of critical pedagogy as an English Language Teaching (ELT) approach in Indonesia. A brief description of critical pedagogy is given, followed by a detailed rationale for its use including an overview of critical pedagogy studies done in Asia, an exploration of the curriculum and teaching approach decreed by the Indonesian Ministry of Education and Culture, and calls for critical pedagogy by Indonesian scholars and teachers. This paper will conclude with some beginning steps that can be undertaken by teachers who want to implement a more critical approach to teaching.
\end{abstract}

Keywords: critical pedagogy, banking approach, transformative approach, dialogue, code, negotiated syllabus

English is a compulsory subject for secondary school students in Indonesia. Unfortunately, despite studying English for six years in junior and senior high school, overall Indonesian students exhibit low proficiency in English upon graduation from senior high school (Imperiani, 2012; Lie, 2007; Marcellino, 2008). This is attributed to many factors including: large class sizes, the low English proficiency of teachers, low salary, not enough teacher education to teach the new curriculum, and cultural barriers hindering teachers from adopting a facilitator role in the English as a foreign language (EFL) class (Dardjowidjojo, 2000; Nur, 2004). It could also be argued that this is a result of the curriculum not reflecting the needs and local contexts of the learners and a negative result of the banking approach (Freire, 1997) that is used in English 
language teaching (ELT) in Indonesia (Marcellino, 2008; Hayati, 2010). Many have commented on the need to change this teacher centered, banking style approach to ELT in Indonesia so that more learning takes place (Coleman 1987; Imperiani, 2012, Musthafa, 2002; Marcellino, 2008). Critical pedagogy could be one way to make the EFL curriculum more meaningful and locally relevant to Indonesian students which could result in better language proficiency. In this paper I will briefly describe critical pedagogy and then move on to providing a rationale for its use in the EFL classrooms in Indonesia. The paper will conclude with a description of some beginning steps that ELT professionals in Indonesia can take to begin to implement a more critically orientated pedagogy that takes into account the local problems and issues faced by their students in their classes.

\section{CRITICAL PEDAGOGY}

Critical pedagogy is mainly attributed to the work and philosophy of Paulo Freire. In a nutshell critical pedagogy is a learner-centered approach to education that is focused on problem posing in which the students engage in critical dialogue. This approach has the aim of improving social justice with an emphasis on action. Duncan-Andrade and Morrell (2007, p. 183) summarize critical pedagogy quite nicely as

an approach to education that is rooted in the experiences of marginalized peoples; that is centered in a critique of structural, economic, and racial oppression; that is focused on dialogue instead on a one way transmission of knowledge; and that is structured to empower individuals and collectives as agents for social change (as cited in Hayati, 2010, p.80).

This transformative approach is contrasted to a banking approach to education "in which the students are the depositories and the teacher is the depositor" of knowledge (Freire, 1997, p. 53). The banking approach to education maintains the status quo whereas the transformative approach challenges it (Freire, 1997).

Some key Freirean concepts of critical pedagogy include problem posing, dialogue, praxis, and codes. In critical pedagogy problems are posed by the learners, which forms the main content of the lesson; this is called problem 
posing. Freire's problem-posing educational method includes three stages, "listening, dialogue, and action" (Wallerstein, 1987, p. 35). Dialogue is key to problem posing. According to Freire (1997), "problem-posing education regards dialogue as indispensable to the act of cognition which unveils reality" (p. 64). Dialogue requires critical thinking and equality among all participants (Freire, 1997). Praxis, another key component of critical pedagogy, is "reflection and action" (Freire, 1997, p. 106). Praxis consists of an ongoing cycle of reflection that leads to action that results in more reflection, further action, and so forth. Codes are "concrete physical expressions" that represent all of the aspects of a theme surrounding a problem and "they can take many forms: photographs, drawings, collages, stories, written dialogues, movies, songs" (Wallerstein, 1983, p.19). They are used to promote critical thinking and dialogue.

Wallerstein (1983) nicely outlines some basic steps for critical pedagogy. First the instructor listens to the learners and identifies their problems. Then the instructor provides codes based on the problems identified by the students to elicit further critical thinking and dialogue. Within this process students should "name the problem, understand how it applies to them, determine the causes of the problem, generalize to others, and finally, suggest alternatives or solutions to the problem" (Wallerstein, 1983, p. 17). The last of these steps involves action on the part of the learners.

It is important here to note that there is not one sole kind of critical pedagogy. Critical pedagogy is flexible so that it can fit the local context of the learning (Morgan 1998; Crookes, 2013; Norton and Toohey, 2004). This is highlighted when we look at Norton and Toohey's edited collection Critical Pedagogies and Language Learning (2004). Right from the beginning in the title we can see that pedagogy is used in the plural and in their introduction they state, "critical pedagogy cannot be a unitary set of texts, beliefs, convictions, or assumptions" (p. 2). Since critical pedagogy is flexible and its aim is to use experiences and issues that are directly relevant to the students as the learning material it makes sense to use critical pedagogy in a nation as diverse as Indonesia. Indonesia needs a more flexible ELT approach that takes into account the diversity that exists in the classroom. I will argue that critical pedagogy not only can but should be implemented in EFL classrooms throughout Indonesia as it is by its very nature a more meaningful approach to ELT. 


\section{RATIONALE FOR CRITICAL PEDAGOGY IN EFL INSTRUCTION IN INDONESIA}

Coleman (1996) in his analysis of higher education in Indonesia and Britain makes the point that the role of education is different in different societies. This is because of the different roles higher education plays in different contexts. Therefore there is not one correct methodology for teaching in higher education settings. He argues against the myth of the "universality of the academic enterprise" (Coleman, 1996, p. 7). He elaborates his position in reference to EFL further by saying that:

[w]hen making recommendations for innovation in English language methodology, we must carry out the equivalent of an environmental audit of the impact of our proposed changes. In other words, we must seek to predict what the knock-on effect of methodological change is likely to be (p. 13).

When teaching English, not only in higher educational settings, but in any and all educational settings, educators must take many considerations into account, especially what effect the implemented methodology is likely to have on the learning situation. In this section I plan on doing just as Coleman insists above. I will provide a rationale for the use of critical pedagogy in ELT in Indonesia for all different educational contexts.

Many scholars and practitioners have argued against the implementation of (Western) pedagogical imports into EFL classes, because they argue they are not effective in their contexts and adversely affect learning. Sonaiya (2002) has argued that the autonomous method for language teaching is not suitable to the Yoruba people of Sub-Saharan Africa because of a mismatch between the teaching methodology and the culture of the Yoruba. She clearly agrees with Coleman (1996) when she argues that "a teaching method is a product of the society in which it was developed; that is, teaching methods are cultural products...[and] [g]iven this (culture-specific) nature of teaching methods, it becomes pertinent to ask whether teaching methods are globally applicable (p. 107)". LoCastro (1996) looks at the curriculum in Japan based on communicative language teaching (CLT) and makes the argument that this approach is unlikely to be effective because of the mismatch of the approach to the sociocultural context of Japan. LoCastro (1996) lists the following as reasons for the curriculum's ineffectiveness: lack of a high level of communicative compe- 
tence by teachers, lack of teacher education, a banking education system, societal roles and hierarchies, importance of national examinations testing written English, and teacher centered classrooms. Hu (2002) discusses the mismatch between CLT and the culture of learning in China to explain the ineffectiveness of the communicative approach in ELT there. Some of the reasons for this mismatch come from the way Chinese students learn, teacher centeredness of the classroom, learning through reading, teacher authority in the classroom, and the downplay of speaking skills.

Many, along the lines of the scholars and practitioners above, would argue that critical pedagogy will not work in Indonesia as it is a pedagogical import that is not in line with the culture of learning. The reasons they would cite would be similar to the reasons given above: the authority of the teacher, the passiveness of the students, a banking approach to education, and the importance of written examinations. However I will attempt to show that critical pedagogy in fact can be (and has been) implemented successfully in Indonesia for the following reasons: critical pedagogy has been to varying degrees successfully implemented in Asia, including Indonesia; critical pedagogy is not in conflict with the curriculum and objectives as proposed by the Indonesian Ministry of Education and Culture (Kementerian Pendidikan and Kebudayaan, 2013a, 2013b); and the implementation of critical pedagogy has been called for by Indonesian scholars and teachers (Susanti, 2011; Paat, 2011; Wisudo, 2011; Hayati, 2010; and Mambu, 2012).

\section{Critical Pedagogy in Asia}

Despite many disagreeing with the effectiveness of pedagogical imports, critical pedagogy (in some form or another) has been practiced in Asia and with various degrees of success. I am aware of nine instances of critical pedagogy being implemented in Asia (Flowerdew, 2005; Miyo, 2005, as cited in Konoeda \& Watanabe, 2008; Shin \& Crookes, 2005; Sekigawa, Sugino, Mimura, \& Chaikul, 2007; Saft \& Ohara, 2004; Mambu, 2009; Mambu, 2010a, as cited in Mambu, 2012) and one instance of critical pedagogy being integrated into a curriculum but not yet implemented (Konoeda \& Watanabe, 2008). I am also aware of one study where critical pedagogy was implemented in Iran, where the majority of the population is Muslim, like Indonesia. These studies are described below. 
Flowerdew (2005) implemented a more critical approach for one of the aspects of her course. The course was an English for Academic Purposes course at a tertiary institute in Hong Kong. The critical aspect of the curriculum was titled "Why are things the way they are? Who decides? What are the possibilities?" (p. 144). For the critical aspect of this course students were required to complete a task-based group project looking into a school or work related problem. One group of biology students examined the mismatch between the biology curriculum and career prospects upon graduation and recommended more Mandarin courses. Flowerdew (2005) showed that a critical approach to teaching can be implemented alongside more traditional notions of syllabus design.

Miyo (2005, as cited in Konoeda \& Watanabe, 2008, p. 47) reported on a study in a foreign language high school in Korea where Korean students of Japanese as a foreign language critically investigated their school and looked into what "learning" meant for them. Also in Korea, Shin and Crookes (2005), investigated the possibilities of a critical approach to teaching through the use of critically-orientated material and critical dialogue in two EFL classes. They found that students were not resistant to the critical approach to teaching EFL and were able to engage in critical dialogue in English.

Sekigawa et al. (2007) describe three different attempts to incorporate critical pedagogy into EFL classes in Japan including implementing critical literacy into an English conversation course for nursing students, taking a more critical approach in an EFL class for international students, and incorporation of critical pedagogy into leadership education. The objectives for the English conversation course for the nursing students were "(a) to encourage the students to voice their opinions and improve their speaking abilities, and (b) to promote their critical consciousness" (Sekigawa et al., 2007, p. 953). Chaikul (in Sekigawa et al., 2007), who carried out this study, stated that at first it was difficult to implement critical pedagogy because of the students' apprehensions to this different teaching style and because of a lack of sufficient language competence to express opinions. However, Chaikul determined that eventually students were able to use the language to express their opinions and many students made positive comments on the topics discussed in class.

Sekigawa (in Sekigawa et al., 2007) carried out a study of an EFL elective course of international students at a Japanese university that was content based and focused on current issues with a goal of developing reading abilities, selfexpression, critical thinking, and intercultural awareness. Students read and en- 
gaged with essays written by an expatriate African-American journalist who gave "critical insights into the Japanese society and her cross-cultural experiences" (Sekigawa et al., 2007, p. 955). Sekigawa (in Sekigawa et al., 2007) comments that many students had difficulty expressing their opinions. However they were engaged in the group discussions and had opportunities to express themselves in English on topics such as "gender, racism, individualism, globalization, advancing technology, traditional culture, generation gaps, violence, and international marriages" (Sekigawa et al., 2007, p. 958). In addition to this,

students learned that everything they personally experience is linked to the larger society, and everything they see in the society is associated with their individual lives...[and] [b]y critically attending to these international and intercultural issues, their EFL learning not only provided them with improvement of their English language skills and understanding of the abstract concepts but also led them to an examination of their own internationality and interculturality (Sekigawa et al., 2007, p. 958).

Sugino (in Sekigawa et al., 2007) implemented a "weakened form" of critical pedagogy "to nurture students' critical thinking" (p. 958) into leadership education at National Defense Academy. The reason for the implementation of critical pedagogy at this location was because of the multitude of "politically incorrect remarks made by Japanese political leaders and many others" and because of the nature of the school which stresses that "cadets should broaden their perspectives and enrich their sense of humanity" (Sekigawa et al., 2007, p. 958). In the class students focused on topics such as racism, sexism, and lingualism. Content for the course came from multiple sources. They also researched and participated in debates. Sugino (in Sekigawa et al., 2007) comments that the first classes did not go very smoothly because of students' different classroom expectations. Later students' comments reflected how much they gained from this more critically orientated class. Sugino (in Sekigawa et al., 2007) states "they learned not only social issues but also various values and the historical and social backgrounds related to the topics they chose, and the skills for arguing not emotionally but objectively" (p. 961).

In their study with a freshmen EFL class at a large national university in Japan, Saft and Ohara (2004), attempted to "promote critical reflection about gender in Japanese society" (p. 143). Saft and Ohara (2004) specifically stated that they followed a critical perspective based on the education philosophy de- 
veloped by Freire with a focus on dialogue. Their study consisted of a module to investigate the topic of gender. The module lasted four class days. The results of the study show that "students were willing to voice their own opinions and engage in dialogue about gender with [the teacher] and their classmates" (Saft \& Ohara, 2004, p.148). As part of the study the teacher also gave the students a questionnaire that asked about their feelings on gender issues in Japan. The responses to the questions on the questionnaire displayed their critical consciousness.

Despite not being carried out, Konoeda and Watanabe (2008) developed a task-based critical pedagogy that could be implemented into EFL classrooms in Japan. They argued that it could address some of the problems the students are facing. In addition to this they showed that a task-based critical pedagogy was suited to the context.

Sadeghi (2005) describes an EFL class at a language institution in Iran that "investigated how the problem-posing process of learning helped students maintain discussion, dialogue and raise critical consciousness" (p. 282). The purpose of this class was to see if after one semester students in the course changed their "a) definition of social justice, b) recognition of practices relevant to social justice in their organizations, and c) sense of responsibility for contributing to change in the distribution of justice" (Sadeghi, 2005, p.282). The findings from this study show that "the class engaged in discussing issues that were derived from their own living experience, instead of practicing decontextualized exercises" (p. 291).

The above studies are proof that critical pedagogy can and has been successfully implemented in various contexts of Asia. It can be argued that since critical pedagogies have been successful in these contexts in Asia they would also be successful in a country like Indonesia which shares a similar culture of learning. In the next section studies of critical pedagogy in Indonesia will be described in more detail as further evidence that critical pedagogy can and should be implemented in some form or another in EFL classes in Indonesia.

\section{Critical Pedagogy in Indonesia}

According to Mambu (2012) "the seeds of CP in Indonesia have actually grown rapidly especially after the former authoritarian Indonesian second pres- 
ident Soeharto stepped down from power in 1998" (p. 114). However he notes that critical pedagogy in ELT in Indonesia is still lacking.

The only critical pedagogy cases in ELT in Indonesia that I am aware of are Mambu's studies (Mambu 2009; Mambu 2010a, as cited in Mambu, 2012, p. 114). In a teacher educator course for students studying to become English teachers in Indonesia, Mambu (2009) used thematic investigation, as outlined by Freire, to encourage critical dialogue in response to four pictures (codes), an advertisement for McDonalds, a beauty pageant, a crowded city, and a beggar. Prior to the collection of data on the comments that students made in regards to the pictures, the students investigated various themes including: oppression in Indonesian education, conscientization (critical consciousness, see Freire, 1997), and humanizing pedagogy. Through the use of English the students commented and interpreted these pictures with various levels of criticality (Mambu, 2009). The level of criticality of students' comments was determined using a coding system. The breadth of the students' thinking was measured using a number scale (0-2) where the numbers were linked to definitions of levels of critical thinking, 0 being low and 2 being high. The depth of their meaning was measured using a letter scale (A-C) where A represents a poor description and $\mathrm{C}$ represents the deepest level the students were able to express. The breadth and depth scales were placed on a rubric so students could be assessed. After analysis of this data Mambu (2009) concludes that the student teachers "showed various degrees of criticality" (p. 66). Mambu (2010a, as cited in Mambu, 2012, p.114) also instituted a form of critical pedagogy with EFL high school students in Indonesia using a similar structure (thematic investigation) to the class described above. Mambu used the same codes as his previous study and the results of this study show that to varying degrees the students in the class were critical of the codes presented before them.

The above studies in Indonesia are further proof that critical pedagogy can be implemented successfully in Asia where many have claimed the culture of learning is contradictory to a critical approach to ELT. In all of the studies presented previously students were able to engage critically with the materials and topics presented in the class. It can be argued that because of the successes that critical pedagogy has had in Asia it is not in conflict with the culture of learning in Asia and can be a successful ELT approach that can result in improved English proficiency. Since it has been successful it should be implemented on a wider scale throughout Indonesia. In the next section I will continue my rationale for using critical pedagogy in Indonesia by looking at the pedagogical 
approach and curricular objectives proposed by the Indonesian Ministry of Education and Culture.

\section{Critical Pedagogy and the New 2013 Curriculum in Indonesia}

In 2013 the Indonesian Ministry of Education and Culture introduced a new curriculum for public schools from elementary through high school. Under the new curriculum English is a mandatory subject in both junior and senior high school. There are many aspects of the new curriculum that are complementary to critical pedagogy.

Within the new curriculum the pola pikir (thinking patterns) have greatly changed. Many of the changes are in line with the ideas of critical pedagogy. The first change listed in the pola pikir of the new curriculum is "the learning process which was centered on the teacher will become centered on the student. Students must possess choices in the material that will be studied..." (Kementrian Pendidikan dan Budaya, 2013a, 2013b / Larson Translation). As previously mentioned student centeredness and choice is one of the foundations of critical pedagogy. The second change in pola pikir listed is that "the one direction learning process (interaction from teacher to student) will become an interactive learning process (interaction between the teacher and students, the students and society, the environment, and other resources)" (Kementrian Pendidikan dan Budaya, 2013a, 2013b / Larson Translation). This (at least in writing) effectively changes the banking approach to education to a more transformative approach to education which is what Freire (1997) calls for in a more critically orientated pedagogy. In addition to the above changes the fourth change to the pola pikir states that "the passive learning process will become an activesearching learning process" (Kementrian Pendidikan dan Budaya, 2013a, 2013b / Larson Translation). Again this concept is parallel to critical pedagogy. The last change to the pola pikir is that "the passive learning process will become a critical learning process" (Kementrian Pendidikan dan Budaya, 2013a, 2013b / Larson Translation). This is the heart of critical pedagogy, learning based on being critical and not just accepting what is being taught.

In addition to the changes in the pola pikir there have been changes to the material that is taught. In terms of the material taught, within the new curriculum the Indonesian Ministry of Education and Culture is strengthening the materials used by "expanding materials to include those that are relevant to the students" (Kementrian Pendidikan dan Budaya, 2013a, 2013b / Larson Transla- 
tion). Again this is another key component of critical pedagogy. The materials used in critical pedagogy should be relevant to the students to ensure more meaningful education. The materials also need to be relevant to the students so that the students can take what is covered in class and apply it to their lives outside of the classroom that will hopefully lead to some type of action.

Lastly ideas that form the basis of critical pedagogy can be found in the educational philosophy that was proclaimed by the Ministry of Education and Culture in the new 2013 curriculum. The philosophy behind the new curriculum aims to "develop the lives of the people now and in the future" (Kementrian Pendidikan dan Budaya, 2013a, 2013b / Larson Translation). Freire's educational philosophy came from the need to help develop the lives of the underprivileged in Brazil. The educational philosophy supported by the Ministry of Education and Culture in this regard is similar to the educational philosophy behind critical pedagogy.

As can be seen above, many of the ideas that are central to critical pedagogy such as student centeredness, transformative education, relevant materials, and active and critical learning are also found in the new 2013 curriculum that was just instituted in Indonesia by the Ministry of Education and Culture. Therefore critical pedagogy should be tried out on a wider scale in Indonesia as it is not in conflict with the new curriculum.

\section{Calls for Critical Pedagogy in Indonesia}

The implementation of critical pedagogy in Indonesia has been called for by Indonesian scholars and teachers. In general critical pedagogy has been called for in Indonesia by Susanti (2011). She makes the argument that critical pedagogy is very relevant to Indonesia as a means to solving the educational problems that exist in Indonesia that are related to the development of Indonesian politics and economy. Paat (2011) calls for critical pedagogy more specifically in foreign language classes. Wisudo (2011) calls for the implementation of critical literacy at all stages of education in Indonesia. Hayati (2010) and Mambu (2012) call for the implementation of critical pedagogy in EFL contexts in Indonesia. With these calls for critical pedagogy coming from Indonesian scholars and practitioners it is clear that critical pedagogy is not just a pedagogical import. It is valued by those who are most familiar with the issues and problems of education in Indonesia and therefore should be attempted in some form or another. 


\section{IMPLEMENTING CRITICAL PEDAGOGY IN INDONESIA: BEGIN- NING STEPS}

In this final section I will describe two helpful tools that EFL teachers can use for beginning to implement a more critically orientated pedagogy in EFL classes in Indonesia. These tools are the negotiated syllabus (Clarke, 1991) and codes (Freire, 1997: Wallerstein, 1983, 1987).

\section{The Negotiated Syllabus}

The negotiated syllabus is defined by it is unique quality that "allows full learner participation in selection of content, mode of working, route of working, assessment, and so on" (Clarke, 1991, p. 13). Within the syllabus "the learner's needs are of paramount importance" (Clarke, 1991, p.13). The learners are key players in the decision making process. The use of a negotiated syllabus works towards equalizing the power hierarchy within the student-teacher relationship by allowing the learners to contribute to the discussion of topics, materials, assessment, etc. Shortening the power distance between student and teacher is one of the essential aspects of critical pedagogy according to Freire (1997). The negotiated syllabus can constitute the first step in critical pedagogy, which was described previously as to listen. By using a negotiated syllabus the teacher is listening to the issues faced by the students and incorporating them into the materials that will be used for class.

In most situations a full negotiation of the syllabus is out of the question. Clarke (1991) mentions many reasons why a full negotiation of a syllabus may not work. The reasons he gives include that: it increases demands on teachers, it would not be practical where there is an emphasis on exams, it is in contradiction with the culture of learning in different contexts, and it is impractical for young and low level learners. However he does mention that a semi negotiated syllabus could also be beneficial for learners as it helps localize the material. I think it is important to note here that any attempt (even small) at allowing students to have more control over the decision making process is better than nothing as it will help equalize the power relationships present in the classroom and help ensure that the content of the course is more relevant to learners, critical components in any critical pedagogy orientated class. As Crookes (2013) states any move towards critical pedagogy is better than nothing and any teach- 
er who is interested in implementing a more critically oriented approach needs to start somewhere.

As one first step to implementing a more critically orientated approach in the ELT, teachers can try out a semi-negotiated syllabus where students have some choice in the materials, topics, assessment, etc. for their courses. Explicitly ask your students what topics they are interested in and what problems or issues they are facing in their everyday lives. This can be done through a questionnaire, survey, or class discussion. If necessary some of this negotiation could be done in the first language. Critical pedagogy is not averse to using the first language in the second language classroom as it may help with negotiation of meaning.

The teacher has the most experience to decide what amount of negotiation of syllabus would work for their class. Teachers may be constrained by a mandated syllabus and predetermined set of materials where there may not be room for much negotiation but again any little bit is better than nothing.

\section{Codes}

In addition to using a semi negotiated syllabus, one way to begin to approach learning in a more critical way would be to use codes, in the Freirean sense of the word. Again as described above codes are "concrete physical expressions" that represent all of the aspects of a theme surrounding a problem and "they can take many forms: photographs, drawings, collages, stories, written dialogues, movies, songs" (Wallerstein, 1983, p.19). They are used to promote critical thinking and dialogue. Codes according to Wallerstein (1983) should be used once problems have been identified by the teacher after listening to their students. When using a code students again should "name the problem, understand how it applies to them, determine the causes of the problem, generalize to others, and finally, suggest alternatives or solutions to the problem" (Wallerstein, 1983, p. 17). With the advance in technology codes are everywhere. Newspaper articles, YouTube videos, cartoons, drawings, commercials, magazine ads, short stories, and blogs can all be used as codes.

Again many teachers may be restricted by a predetermined curriculum but the use of codes could be implemented periodically to take a critical look at some of the topics that are addressed in the typical EFL class in Indonesia. Many common topics addressed in EFL classes in Indonesia include the fami- 
ly, occupations, travel to an English speaking country, and carrying out everyday activities (e.g. shopping and eating out). All of these topics could be investigated in a more critical light through the use of codes. Again even if this was done to a small extent it would be better than nothing.

\section{CONCLUSIONS AND SUGGESTIONS}

I have argued in this paper that critical pedagogy is a viable ELT method that could be rationally implemented in Indonesia. Its implementation would result in a move from a banking approach to education to a more transformative approach (Freire, 1997). This would not only make the materials more relevant and meaningful to the learners and hopefully result in increased language proficiency but would also raise students' awareness to the issues and problems they face in their everyday lives. Critical pedagogy is viable in Indonesia because critical pedagogies of some form or another have been successfully implemented in the Asian context, critical pedagogy is not in conflict with the ELT approach and curricular objectives supported by the Indonesian Ministry of Education and Culture, and lastly critical pedagogy has been called for by Indonesian scholars and teachers. The evidence in this paper provides support for the use of critical pedagogy in EFL classes throughout Indonesia. Finally this paper provided two tools that EFL teachers in Indonesia could use to begin to implement a more critically orientated pedagogy: the negotiated syllabus and codes. My hope is that those reading this paper are now convinced that critical pedagogy is not only possible in Indonesia but it is a more meaningful approach to teach the English language there.

\section{REFERENCES}

Clarke, D. F. (1991). The negotiated syllabus: what is it and how is it likely to work? Applied Linguistics, 12(1), 13-28.

Coleman, H. (1987). Teaching spectacles and learning festivals. ELT Journal, 41(2), 97-103.

Coleman, H. (1996). Shadow puppets and language lessons: Interpreting classroom behaviour in its cultural context. In H. Coleman (Ed.), Society and 
the language classroom (pp. 64-85). Cambridge: Cambridge University Press.

Crookes, G. (2013). Critical ELT in action: Foundations, promises, praxis. New York: Routledge.

Dardjowidjojo, S. (2000). English teaching in Indonesia. EA Journal, 18(1), 22-30.

Flowerdew, L. (2005). Integrating traditional and critical approaches to syllabus design: The 'what', the 'how'and the 'why?' Journal of English for Academic Purposes, 4(2), 135-147.

Freire, P. (1997). Pedagogy of the oppressed. New York: Continuum.

Hayati, N. (2010). Empowering non-native English speaking teachers through critical pedagogy. TEFLIN Journal, 21(1), 78-89.

Hu, G. (2002). Potential cultural resistance to pedagogical imports: The case of communicative language teaching in China. Language Culture and Curriculum, 15(2), 93-105.

Imperiani, E. (2012). English language teaching in Indonesia and its relation to the role of English as an international language. Passage, 1(1), 1-12.

Kementrian Pendidikan dan Kebudayaan (Ministry of Education and Culture) (2013a). Kerangka dasar dan struktur kurikulum sekolah menengah pertama/madrasah tsanawiyah.

Kementrian Pendidikan dan Kebudayaan (Ministry of Education and Culture) (2013b). Kerangka dasar dan struktur kurikulum sekolah menengah atas/madrasah Aliyah.

Konoeda, K., \& Watanabe, Y. (2008). Task-based critical pedagogy in Japanese EFL classrooms: Rationale, principles, and examples. In M. Mantero, C. P. Miller, \& J. L. Watzke (Eds.), Readings in Language Studies (Vol. 1). St. Louis, MO: International Society for Language Studies.

Lie, A. (2007). Education policy and EFL curriculum in Indonesia: Between the commitment to competence and the quest for higher test scores.

TEFLIN Journal, 18(1), 1-14. 
LoCastro, V. (1996). English language education in Japan. In H. Coleman (Ed.), Society and the language classroom (pp. 40-58). Cambridge: Cambridge University Press.

Mambu, J. E. (2009). Thematic investigations with Indonesia EFL pre-service teachers: From descriptions to social critiques and beyond. Indonesian Journal of English Language Teaching, 5(1), 57-78.

Mambu, J. E. (2012). English for advocacy purposes: Critical pedagogy's contribution to Indonesia. In K. Sung \& R. Pederson (Eds.), Critical ELT practices in Asia (pp. 111-136). Rotterdam: Sense Publishers.

Marcellino, M. (2008). English language teaching in Indonesia: A continuous challenge in education and cultural diversity. TEFLIN Journal, 19(1): 5769.

Morgan, B. (1998). The ESL classroom: Teaching, critical practice, and community development. University of Toronto Press.

Musthafa, B. (2002). English teaching in Indonesia: Status, issues and challenges. ESL Magazine, 5(1), 26-28.

Norton, B., \& Toohey, K. (Eds.). (2004). Critical pedagogies and language learning. Cambridge: Cambridge University Press.

Nur, C. (2004). English language teaching in Indonesia: Changing policies and practical constraints. In H. W. Kam \& R. Y. L. Wong (Eds.). English language teaching in East Asia today: Changing policies and practices (pp. 178-186). Singapore: Eastern Universities Press.

Paat, J. (2011). Pedagogik kritis dan pengajaran bahasa asing [Critical pedagogy and the teaching of foreign language]. In H. A. R. Tilaar, J. Paat, \& L. Paat (Eds.). Pedagogik kritis: Perkembangan, substansi, dan perkembangannya di Indonesia [Critical pedagogy: Its growth, substance, and development in Indonesia]. Jakarta: Rineka Cipta.

Sadeghi, S. (2005). Critical pedagogy in an EFL teaching context: An ignis fatuus or an alternative approach. Journal of Critical Education Policy Studies, 6(1), 1-9.

Saft, S. \& Ohara, Y. (2004). Promoting critical reflection about gender in EFL classes at a Japanese university. In B. Norton \& A. Pavlenko (Eds.). Gen- 
der and English language learners (pp. 143-154). Alexandria, VA: Teachers of English to Speaker of Other Languages, Inc.

Sekigawa, Y., Sugino, T., Mimura, C., \& Chaikul, R. (2007). Taking a critical pedagogic turn in L2 teaching. In K. Bradford-Watts (Ed.), JALT2006 Conference Proceedings (pp. 948-964). Tokyo: JALT. Retrieved from http://jaltpublications.org/archive/proceedings/2006/E034.pdf

Shin, H., \& Crookes, G. (2005). Exploring the possibilities for EFL critical pedagogy in Korea: A two-part case study. Critical Inquiry in Language Studies, 2(2), 113-136.

Sonaiya, R. (2002). Autonomous language learning in Africa: A mismatch of cultural assumptions. Language Culture and Curriculum, 15(2), 106-116.

Susanti, D. (2011). Mengapa pedagogik kritis yang berkenadilan sosial sulit dijadikan pedagogik bagi pendidikan formal?: Sebuah provakasi. [Why is critical pedagogy, which focuses on social justice, difficult to become the pedagogy for formal education?: A provocation]. In H. A. R. Tilaar, J. Paat, \& L. Paat (Eds.). Pedagogik kritis: Perkembangan, substansi, dan perkembangannya di Indonesia [Critical pedagogy: Its growth, substance, and development in Indonesia]. Jakarta: Rineka Cipta.

Wallerstein, N. (1983). Language and culture in conflict: Problem-posing in the ESL classroom. Reading, MA: Addison-Wesley Publishing Company.

Wallerstein, N. (1987). Problem-posing education: Freire's method for transformation. In I. Shor (Ed.). Freire for the classroom: A sourcebook for liberatory teaching (pp. 33-44). Portsmouth, NH: Boynton, Cook, Heinemann.

Wisudo, B. (2011). Literasi kritis, alternatif melawan pendangkalan pembelajaran di sekolah. [Critical literacy, the alternative to combat the superficiality of study in school]. In H. A. R. Tilaar, J. Paat, \& L. Paat (Eds.). Pedagogik kritis: Perkembangan, substansi, dan perkembangannya di Indonesia [Critical pedagogy: Its growth, substance, and development in Indonesia]. Jakarta: Rineka Cipta. 